\title{
Riparian quality and habitat heterogeneity assessment in Cantabrian rivers
}

\author{
José Barquín ${ }^{1, *}$, Diego Fernández ${ }^{1}$, Mario Álvarez-Cabria ${ }^{1}$ and Francisco Peñas ${ }^{1}$
}

${ }^{1}$ Environmental Hydraulics Institute, University of Cantabria, Avda. Los Castros s/n, 39005 Santander, Cantabria, Spain.

* Corresponding author: barquinj@unican.es

Received: 20/5/2010

Accepted: 9/8/2011

\begin{abstract}
Riparian quality and habitat heterogeneity assessment in Cantabrian rivers

In this study, we attempted to assess riparian quality and river habitat heterogeneity as part of the conservation status assessment of the Habitats Directive (EC, 1992) in the rivers included in the Nature 2000 network of Cantabria, Northern Spain. We chose the Qualitat del Bosc de Ribera (QBR) and the Riparian Quality Index (RQI) to assess riparian quality and the Índice de Habitabilidad Fluvial (IHF) and Habitat Quality Assessment (HQA) to assess the river habitat heterogeneity. The present study aims to compare the performance of the QBR and RQI for assessing riparian quality (RQ) and of the IHF and HQA for assessing river habitat heterogeneity (RHH). With a higher score in each index, the site has a higher likelihood of belonging to a reference condition and also of reaching a higher biological integrity. Thus, we used logistic binary regressions of RQ and RHH to determine the relationships between the attributes evaluated by each of the four indices and reference/non-reference conditions. We also looked into the relationships between RQ and RHH as well as between these indices and the local macroinvertebrate communities. We surveyed riparian vegetation and river habitat characteristics in a total of 285 river reaches, each $500 \mathrm{~m}$ in length, along the fluvial network of Cantabria. These data were combined with previous macroinvertebrate community records from a total of 52 river reaches, and the Index of Average Score per Taxon (IASPT) metric was calculated for comparison. Reference condition sites were selected in 10 river types for the purpose of the present study on the basis of (1) unaltered discharge, (2) non-intensive land uses and (3) no or minimal morphological changes. There were 96 river reaches that matched the reference conditions. QBR and RQI were sensitive to both reference and nonreference conditions in the official river types and were larger in reference conditions than in non-reference conditions for most of the river types. However, IHF and HQA could only differentiate some of the river types and could not distinguish between reference and non-reference conditions. Moreover, IHF and HQA did not have a similar response to human modifications across river types, as reference reaches presented larger or lower values than non-reference conditions depending on the river type. Finally, RQ was positively correlated to RHH, and IASPT increased with both. We concluded that RQI and HQA performed slightly better than QBR and IHF indices to distinguish between reference and non-reference sites in the rivers of Cantabria and that river habitat heterogeneity should not be used to assess river habitat quality.
\end{abstract}

Key words: River ecosystems, Hydromorphology, River health, River habitat quality, Ecological status.

\section{RESUMEN}

\section{Calidad riparia y evaluación de la heterogeneidad del hábitat en ríos Cántabros}

En este estudio se intentó evaluar la calidad riparia y la heterogeneidad del hábitat fluvial como parte de la evaluación del estado de conservación de la Directiva Hábitats (CE, 1992) en los ríos incluidos en la red Natura 2000 de Cantabria, norte de España. Entre los métodos existentes elegimos los índices Qualitat del Bosc de Ribera (QBR) y "Riparian Quality Index" (RQI) para evaluar la calidad de la ribera, y el Índice de Habitabilidad fluvial (IHF) y el "Habitat Quality Assessment" (HQA) para evaluar la heterogeneidad del hábitat fluvial. El presente estudio pretende comparar el rendimiento del QBR y RQI para evaluar la calidad ribereña (RQ) y del IHF y HQA para evaluar la heterogeneidad del hábitat fluvial (RHH). Cuanto mayor sea la puntuación de los índices en un tramo de río, más alta es la probabilidad de que pertenezca a una condición de referencia, y también de que alcance una mayor integridad biológica. Por lo tanto, se utilizó la regresión logística binaria elaborando un modelo para $R Q$ y otro para RHH, con el fin de examinar las relaciones entre los atributos evaluados por 
cualquiera de los cuatro índices y las condiciones de referencia y de no-referencia. También nos fijamos en las relaciones entre $R Q$ y RHH y de ambos con las comunidades de macroinvertebrados. Se muestrearon la vegetación ribereña y las características del hábitat fluvial en un total de 285 tramos de 500 metros de longitud a lo largo de la red fluvial de Cantabria. Estos datos fueron comparados con datos existentes sobre la comunidad de macroinvertebrados en un total de 52 tramos de ríos y la métrica IASPT se calculó para las comparaciones. En este estudio, las condiciones de referencia se fijaron en 10 tipologías fluviales de acuerdo a los siguientes criterios: (1) régimen hidrológico inalterado, (2) usos del suelo no intensivos y (3) sin presencia o mínimos cambios morfológicos, terminando con un total de 96 tramos de río seleccionados. QBR y RQI fueron sensibles a las condiciones de referencia y a las tipologías fluviales, siendo mayor en condiciones de referencia en la mayoría de los tipos fluviales. Sin embargo, IHF y HQA sólo presentaron diferencias dependiendo del tipo fluvial y no en función de las condiciones de referencia. Por otra parte, IHF y HQA no tienen una respuesta similar a la modificación humana en todas las tipologías de río, ya que los tramos en condiciones de referencia presentaron valores más altos o más bajos que los tramos en condiciones de no-referencia en función de las tipologías fluviales. Por último, RQ se correlacionó positivamente con RHH, y el IASPT aumentó con ambos. Llegamos a la conclusión de que RQI y HQA obtuvieron ligeramente mejores resultados que el QBR y IHF para distinguir entre sitios en condiciones de referencia y no referencia en los ríos de Cantabria, y que la heterogeneidad del hábitat fluvial no debe ser utilizada para evaluar la calidad del hábitat fluvial.

Palabras clave: Ecosistemas fluviales, Hidromorfología, Salud del río, Calidad del hábitat fluvial, Estado ecológico.

\section{INTRODUCTION}

The physical river habitat characteristics constitute the setting in which fluvial fauna and flora dwell and thrive (Allan, 1996). Most studies that consider local or regional patterns of fluvial biota characterise the physical river habitat using different variables, such as water velocity, channel substrate composition, bank materials, and other parameters, depending on the purpose of the study (Elosegi et al., 2011). Riparian forest characteristics are also described when research is focused on patterns in algal (e.g., Quinn et al., 1997), macrophyte (e.g., Haury \& Aïdara, 1999), fish (e.g., Kauffmann et al., 1997) or macroinvertebrate communities (e.g., Lester et al., 1994). Riparian forests are, in fact, an extremely important component of river ecosystems and they influence many riverine physical habitat characteristics and processes (Naiman et al., 2005). For example, riparian canopy is a determinant of channel shade (Davies-Colley \& Rutherford, 2005), while wood recruitment in riparian forests determines the amount of large woody debris in the river channel; large woody debris play an important role in determining mesohabitat sequences (Brooks et al., 2003), velocity patterns, substrate composition and in-stream habitat heterogeneity (Elosegi et al., 2010). Thus, when the riparian zone and river habitat characteristics are close to pristine conditions and there is no other human alteration, the integrity of fluvial biological communities is expected to be at its highest (i.e., natural; Stoddard et al., 2006).

The evaluation of riverine ecosystem health should take into account the importance of riparian and physical habitat characteristics in river ecosystems so that biological impairments of river reaches could be related not only to changes in water quality but also to changes in river morphology. In this regard, the Water Framework Directive (WFD; EC, 2000) in Europe demands the determination of riverine hydromorphological quality, in which channel patterns, variations in depths and widths, flow conditions, substrate composition and both composition and structure of the riparian zone must be part of the ecological status assessment. Despite the establishment of this directive, only some of the previously used methods for assessing river habitat quality in European rivers incorporate the characteristics of the river channel, banks and floodplains (Fernández et al., 2011), although using a combination of methods could satisfy the existing legal requirements (Ferreira et al., 2011).

The existing methods for evaluating the quality of riparian zones in Spain are the "Qualitat del Bosc de Ribera" and the "Índice de Vegetación 
Fluvial" (QBR and IVF, respectively; Munné $e t$ al., 2003; Munné et al., 2006), the Riparian Quality Index (González del Tánago et al., 2006; González del Tánago \& García de Jalón, 2011) and the Riparian Forest eValuation (RFV; Magdaleno et al., 2010). The QBR and RQI indices have been successfully applied in Spain and elsewhere (Acosta et al., 2009; Navarro-Llácer et al., 2010), while the IVF requires a much more detailed floristic description, which might have prevented its wider application. There is a lack of methods in Spain that strictly evaluate the channel, bank or floodplain habitat characteristics, although there are methods that assess river habitat heterogeneity (RHH), such as the "Índice del Habitabilidad Fluvial" (IHF; Pardo et al., 2002) and the degree of river habitat modification (IHG; Ollero et al., 2008; Ollero et al., 2011). However, most water agencies and studies evaluating the quality of river habitats in Spain use the IHF, (i.e., an RHH estimate) as a surrogate for river habitat quality (e.g., Jáimez-Cuéllar et al., 2002). This contrasts with the large number of methods that are used to evaluate the quality of river habitat characteristics elsewhere in Europe (e.g., SEQ-Physique, LAWA, EcoRibHab; for a review see Fernández et al., 2011). Among the European methods, the River Habitat Survey protocol (RHS; Raven et al., 1997) has been successfully applied to rivers from different European countries and also from northern Spain (Raven $e t$ $a l ., 2010)$. This river habitat characterisation protocol provides information from the river channel, banks and floodplain, and different indices can be derived from the information gathered, such as the Habitat Quality Assessment (HQA) that evaluates river habitat heterogeneity or the Habitat Modification Score (HMS), which evaluates the degree of habitat modification due to anthropological pressures (Raven et al., 1997; Environment Agency, 2003).

In the present study, we assessed riparian and river habitat heterogeneity in the fluvial Special Areas of Conservation of Cantabria, Northern Spain, following the requirements of the Habitats Directive (HD; EC, 1992) to evaluate the conservation status of different riverine species and habitats (sensu phytosociological associa- tions). Although the methodology used to evaluate the conservation status of habitats and species within the Nature 2000 network is still in debate, the conservation status assessment in riverine ecosystems should certainly incorporate hydrological, connectivity, channel and riparian characteristics (Joint Nature Conservation Committee, 2007; Barquín et al., 2012). Regarding hydrological and river longitudinal connectivity, the "Indices de Alteración Hidrológica en Ríos" methodology (IAHRIS; Martínez \& Fernandez 2006) and the "Índice de Conectividad Fluvial" (ICF; Munné et al., 2006; Solà et al., 2011), respectively, have been successfully incorporated into the HD conservation status assessment (GESHA, 2008) in Cantabria. However, a decision must be taken regarding the methods to use to assess riparian and river habitat quality.

The objectives of the present study can be summarised as follows: (1) the comparison of QBR and RQI indices to evaluate riparian quality (RQ) in reference versus non-reference sites in Cantabrian rivers, (2) the comparison of IHF and HQA (from RHS) indices to assess river habitat heterogeneity in reference $v s$. non-reference sites, and (3) to evaluate the possibility of using these indices as indicators of river habitat quality in the Cantabrian rivers. Finally, RQ should be positively correlated with RHH, as described above, and both of these factors should be associated with an increase in invertebrate community integrity (Minshall \& Robinson, 1998; Muotka \& Laasonen, 2002). In order to confirm these expectations, we (4) investigated the relationships between RQ and RHH and of both of these indices with local macroinvertebrate communities.

\section{MATERIALS AND METHODS}

\section{Study area}

The study area comprised river catchments in the province of Cantabria, northern Spain, that drain into the Cantabrian Sea, the Atlantic Ocean and the Mediterranean Sea (Fig. 1). Cantabria is a mountainous and coastal region, and both of those characteristics play an important role 


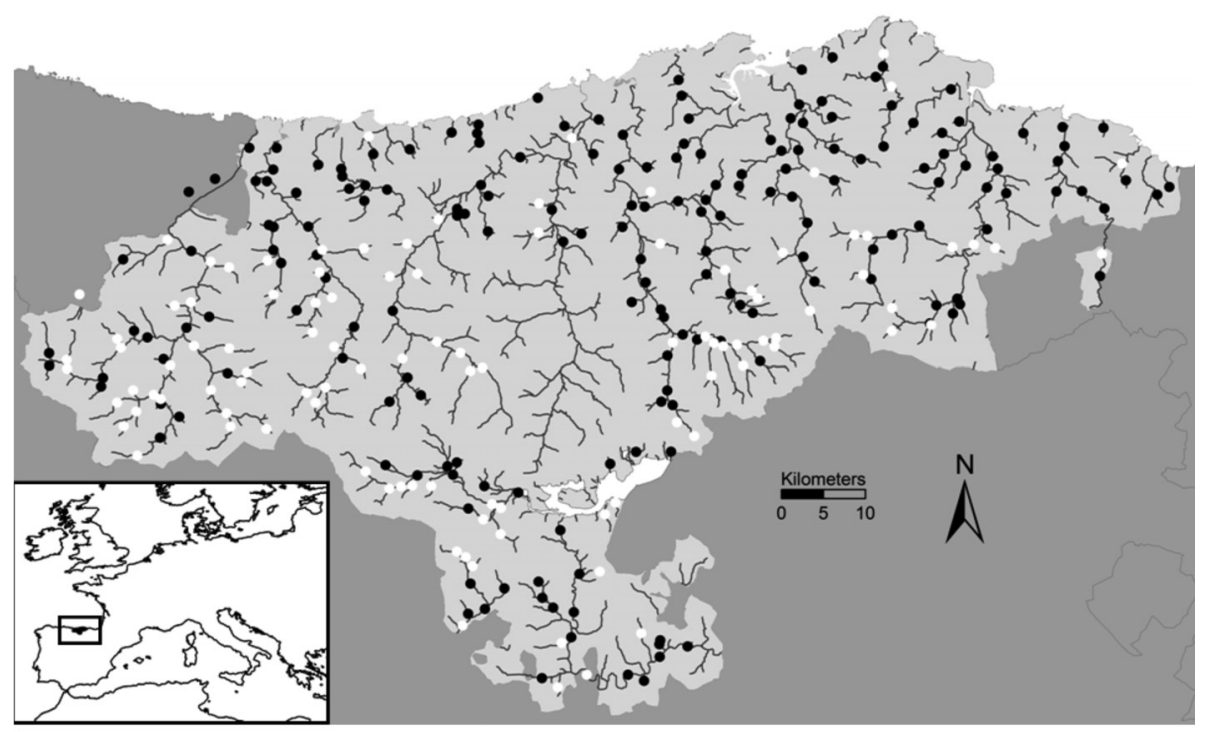

Figure 1. Cantabrian river network, northern Spain, and reference (o) and non-reference sites (•) surveyed for assessing riparian quality and habitat heterogeneity in the summer of 2008. Red fluvial de Cantabria, Norte de España, y sitios de referencia (o) y de no-referencia $\bullet \bullet$ muestreados para evaluar la calidad riparia y la heterogeneidad del hábitat en el verano de 2008.

in determining the climate and river morphology. Near the coast, valleys are below $400 \mathrm{~m}$ in altitude; however, as we move inland we find the Cordillera Cantábrica mountain range. This range runs from west to east parallel to the sea reaching its highest peaks more than $2600 \mathrm{~m}$ a.s.1 in the south west of the region. The inland valleys run from south to north with high slopes and containing short torrential rivers with high erosive power. Between the coast and the Cordillera Cantábrica, there are other mountain ranges, such as the Sierra del Escudo that is up to $1000 \mathrm{~m}$ in altitude. Cantabria has a humid oceanic temperate climate with an average annual temperature of $14{ }^{\circ} \mathrm{C}$ and an average annual precipitation of about $1200 \mathrm{~mm}$. Rainfall is regularly distributed throughout the year with maximums in winter and spring and storms occurring in any season. Precipitation in the form of snow is common from late autumn to early spring on the mountain ranges.

The high altitude range produces a clear vegetation zonation. The north is characterised by Euro-Siberian vegetation, composed of deciduous forest, whilst in the south there is a transition from Euro-Siberian to Mediterraneantype vegetation. The riparian vegetation along the Cantabrian rivers up to $700 \mathrm{~m}$ in altitude is dominated by groves or galleries of alder (Alnus glutinosa; Lara et al., 2004). Willow groves formed by Salix atrocinerea (northern Cantabrian cordillera) and S. cantabrica (southern Cantabrian cordillera) replace alder where soils are thin or where there are large fluctuations in the river level. Higher up, alder is replaced by ash (F. excelsior) or hazel (C. avella$n a$ ), whilst in steep valleys, beech (Fagus sylvatica), oak (Q. robur and $Q$. petrea) and mixed Atlantic forest vegetation dominate the riparian forest. Where natural riparian forests have been modified by human activity, the vegetation is usually dominated by brambles (Rubus spp.), roses (Rosa spp.), hawthorn (Crataegus monogyna) and blackthorn scrub (Prunus spinosa). Pastureland has also been created, eliminating many of the native forest. Average population density is 103 inhabitants $\mathrm{km}^{-2}$, with towns and cities concentrated along the coast. The main urban centre of Santander has 184000 inhabitants.

Three different water agencies, the Cantabric, Duero and Ebro river basin authorities, are in charge of the water management in the region of Cantabria, and the rivers within the region are now categorised into eight official river types for the application of the WFD (Table 1). However, 
Table 1. Official river types located in the province of Cantabria in northern Spain. The codes used in this study and the slopes that these types drain are also indicated. Tipologías de río oficiales localizadas en Cantabria, Norte de España. Se indican también los códigos utilizados en este estudio y las vertientes que estas tipologías drenan.

\begin{tabular}{rll}
\hline Code & Description & Slope \\
\hline $\mathbf{1}$ & 29. Calcareous Cantabro-Atlantic main fluvial axis & Northern \\
$\mathbf{2}$ & 32. Calcareous Cantabro-Atlantic small fluvial axis & Northern \\
$\mathbf{3}$ & 22. Calcareous Cantabro-Atlantic rivers & Northern \\
$\mathbf{4}$ & 30. Cantabro-Atlantic coastal rivers & Northern \\
$\mathbf{5}$ & 27. Mountain rivers & Mediterranean \\
$\mathbf{6}$ & 26 a. Calcareous wet mountain rivers & Northern \\
$\mathbf{7}$ & 26 b. Calcareous wet mountain rivers & Mediterranean / Atlantic \\
$\mathbf{8}$ & 12 a. Calcareous Mediterranean mountain rivers with high conductivity & Mediterranean \\
$\mathbf{9}$ & 12 b. Calcareous Mediterranean mountain rivers with low conductivity & Mediterranean \\
$\mathbf{1 0}$ & 15. Continental-Mediterranean axis with low conductivity & Mediterranean \\
\hline
\end{tabular}

for this study, we have kept the 10 river classes that have been established by previous studies because rivers within the calcareous wet mountain river and calcareous Mediterranean mountain river classes (river types $6,7,8$ and 9 in Table 1) do have large differences in altitude, valley shapes and gradients that can influence riparian vegetation composition and structure and the river habitat characteristics. These 10 river types have been used to analyse how RQ and $\mathrm{RHH}$ indices perform in different river environmental settings because index scores in reference condition river reaches might differ substantially between river types.

\section{Field data collection}

The QBR and RQI indices were used to assess RQ and the IHF and HQA indices were used to assess $\mathrm{RHH}$ in a total of 285 river reaches of $500 \mathrm{~m}$ in length along the fluvial network of Cantabria from June to September of 2008. QBR, RQI and IHF indices were chosen because they were the best indices currently available for the purpose of the study, and they have also been commonly used by water agencies and consultancies in Spanish rivers and elsewhere (Acosta et al., 2009; Navarro-Llácer et al., 2010; Garófano-Gómez et al., 2011). Moreover, other indices used outside of Spain for evaluating riparian quality were not known, and those that have been used in Spanish rivers were not completely developed at the moment of the sur- vey, such as the RFV (Magdaleno et al., 2010); others require a much more detailed floristic evaluation, such as the IFV (Fluvial Vegetation Index; Munné et al., 2006). Finally, the HQA index was selected because it has been shown to be applicable to rivers from northern Spain (Raven et $a l ., 2009$ ) and elsewhere in Europe (Raven et al., 2010), and it is relatively easy to calculate after following the River Habitat Survey field protocol (Environment Agency, 2003).

The QBR and RQI rate riparian quality into 5 classes (bad, poor, moderate, good and high), with a total score for each river reach ranging from 0 to 100 for the QBR and from 0 to 140 for the RQI. The QBR uses 4 attributes to assess riparian quality (QBR1 to QBR4; Table 2), while the RQI uses 7 attributes (RQI1 to RQI7; Table 2). It is important to note that in this study the first version of the RQI was used instead of the latest updates (González del Tánago \& García de Jalón, 2011). The IHF and HQA do not classify river habitat heterogeneity into classes, so for the purpose of this study we divided the 0 to 100 score range that a river reach can achieve into five classes: $\leq 19$ very low, 20 to 39 low, 40 to 59 moderate, 60 to 79 high and $\geq 80$ very high habitat heterogeneity. The IHF uses 7 attributes to evaluate river habitat heterogeneity (IHF1 to IHF7; Table 2), while the HQA uses 9 (HQA1 to HQA9; Table 2). Field survey protocols and the calculation of all of these indices have been described in depth elsewhere (Raven et al., 1998; Jáimez-Cuéllar et al., 2002; González del Tánago 
Table 2. Indices used in this study to assess riparian quality (QBR and RQI) and habitat heterogeneity (IHF and HQA) in the rivers of Cantabria in northern Spain. The different sections evaluated by each index area also shown. Indices utilizados en este estudio para evaluar la calidad riparia (QBR y RQI) y la heterogeneidad del hábitat (IHF y HQA) en los ríos de Cantabria, Norte de España. También se muestran los diferentes apartados evaluados por cada índice.

\begin{tabular}{llll}
\hline & Qualitat del Bosc de Ribera (QBR) & & Índice de Habitabilidad Fluvial (IHF) \\
QBR1 & Extent of riparian cover & IHF1 & Substrate embeddedness or sediments in pools \\
QBR2 & Riparian cover structure & IHF2 & Rapid frequency \\
QBR3 & Riparian cover quality & IHF3 & Substrate composition \\
QBR4 & Degree of channel naturalness & IHF4 & Velocity / Depth conditions \\
& Riparian Quality Index (RQI) & IHF5 & Channel shade percentage \\
RQI1 & Riparian longitudinal continuity & IHF6 & Heterogeneity elements \\
RQI2 & Riparian zone width & IHF7 & Aquatic vegetation cover \\
RQI3 & Riparian vegetation composition and structure & & Habitat Quality Assessment (HQA) \\
RQI4 & Riparian regeneration & HQA1 & Flow types \\
RQI5 & Bank condition & HQA2 & Channel substrate \\
RQI6 & Lateral connectivity of riparian zone with channel & HQA3 & Channel features \\
RQI7 & Alteration degree of riparian relief and soil & HQA4 & Bank features \\
& & HQA5 & Bank vegetation structure \\
& & HQA6 & In-stream channel vegetation
\end{tabular}

\& García de Jalón, 2011); however, it should be noted that when calculating the final score for a site, only the QBR has both positive and negative values within each evaluated attribute.

To compare the performance of all of the methods, we selected reference condition river reaches in each river type using the following criteria: (1) unaltered discharge by major dams or obstructions, (2) non-intensive land uses $(<10 \%$ of combined industrial, urban, agriculture and forestry plantation land) in the catchment of every evaluated river reach, and (3) none or minimal morphological changes in the channel or riparian zone, selected by eliminating sites with a Habitat Modification Score (HMS) >200 and sites located within $1 \mathrm{~km}$ up- or downstream of weirs. The HMS is calculated using data gathered following the RHS field survey protocol (Environment Agency, 2003). Finally, we did not include riparian vegetation quality criteria to prevent circular arguments.

The data on macroinvertebrate communities from the Cantabrian rivers were compiled from different studies from 2003 to 2007, yielding a total of 122 sites. Macroinvertebrate communities were sampled in all of these sites during the summer (June to September) with a kick handnet of $500 \mu \mathrm{m}$ mesh size in $100 \mathrm{~m}$ river sections and preserved in $70 \%$ ethanol. Every sample was collected by 20 kicks, covering $2.5 \mathrm{~m}^{2}$ of substrate, distributed according to the relative importance of the existing habitats (AQUEM, 2002). In the laboratory, the samples were divided into 3 fractions $(0.5-1 \mathrm{~mm}, 1-5 \mathrm{~mm}$, and $>5 \mathrm{~mm}$ ) and invertebrates were sub-sampled, counting 100 individuals from each fraction and identifying all of the different taxa seen in the two major fractions. Macroinvertebrate identification was done to family level using available keys (Vieira-Lanera, 2000; Tachet et al., 2002).

\section{Data analyses}

Box and whisker plots were used to compare means, medians, and the distribution $(10,25,75$ and 90 percentiles) of QBR, RQI, IHF and HQA 
values between reference and non-reference sites in the 10 different river types in the Cantabrian rivers. The differences among reference and nonreference sites and among river types were tested with a two-way analysis of variance, treating both factors as fixed factors. Heteroscedasticity was removed by log-transforming the data.

To analyse how well RQ and RHH indices correlated with macroinvertebrate communities, we selected the IASPT macroinvertebrate community metric to represent macroinvertebrate community integrity. We selected this metric for several reasons. First, it has been shown to be one of the most seasonally stable metrics in the Cantabrian rivers, with a similar score in both high- and low-flow seasons (Álvarez-Cabria et al., 2010, 2011), which suits our macroinvertebrate dataset. However, the summer months in the selected years had a relatively low hydrological variability with no important floods occurring except in the summer of 2007, and only 3 samples from minor tributaries from that year were included in this study. The coefficient of variance for summer monthly flows reached a maximum of $35 \%$ in September in some of the large rivers, while more than $80 \%$ of the macroinvertebrate sites were sampled in June, July and August in smaller tributaries. This value is low when compared with the coefficients of variance over $200 \%$ that are regularly found in non-summer months in these Cantabrian rivers (based on daily records from 9 official gauging stations in the province of Cantabria). Second, the IASPT has also been shown to be the most sensitive metric to habitat modification in the Cantabrian rivers from a wide range of metrics used by different water authorities in Spain (Álvarez-Cabria et al., 2010, 2011). The IASPT was calculated for all 122 river reaches with available macroinvertebrate community data and then was matched to the nearest of the 285 sites with QBR/RQI and IFH/HQA data. Macroinvertebrate sites were selected if they were within $500 \mathrm{~m}$ of a site with data on physical characteristics and otherwise they were discarded. A total of 52 river reaches throughout the Cantabrian river network were finally included in the analyses.
The rationale behind the applied indices in this study is that the higher the index score, the closer the evaluated river reach is to a reference condition. The score obtained by each index attribute should, then, be correlated with the reference condition if the evaluated attribute is relevant. To test this assumption, we used logistic binary regressions with a stepwise forward procedure to evaluate the adjustment of the different measured attributes of each index, QBR (QBR1 to QBR4), RQI (RQI1 to RQI7), IHF (IHF1 to IHF7) and HQA (HQA1 to HQA9; Table 2), to the reference condition in two separate models, one for RQ and other for RHH. The index attributes selected by the regression will be considered as the most significant evaluated attributes to account for the reference conditions of RQ and RHH. The expected beta values, $\operatorname{Exp}(B)$, of each variable included in the logistic regression will indicate whether larger values of that variable increase the probability of a site belonging to the reference condition $(\operatorname{Exp}(B)>1)$, whether they do not have an effect $(\operatorname{Exp}(B)=1)$ or whether larger values reduce the probability of a site belonging to the reference condition $(\operatorname{Exp}(\mathrm{B})<1)$. The co-linearity was not analysed because the index attributes were expected to be correlated to each other and we wanted to keep all of them in the analysis.

Simple linear regressions were also performed to analyse the relationships between RQ and RHH as well as between those two indices and the IASPT macroinvertebrate community metric. All the analyses were carried out using R software (version 2.7.1; R Development Core Team, 2008).

\section{RESULTS}

A total of $55 \%$ and $61 \%$ of the 285 surveyed river reaches had a good or very good RQ, respectively, which was identified using the QBR and RQI indices. Fifty-five sites reached the maximum score for the QBR (100); however, none of the river reaches reached the maximum score for the RQI (140). A bad RQ was only found in a few river types (4, 6, 7 and 8; Fig. 2), while a high RQ was predominantly found in river 

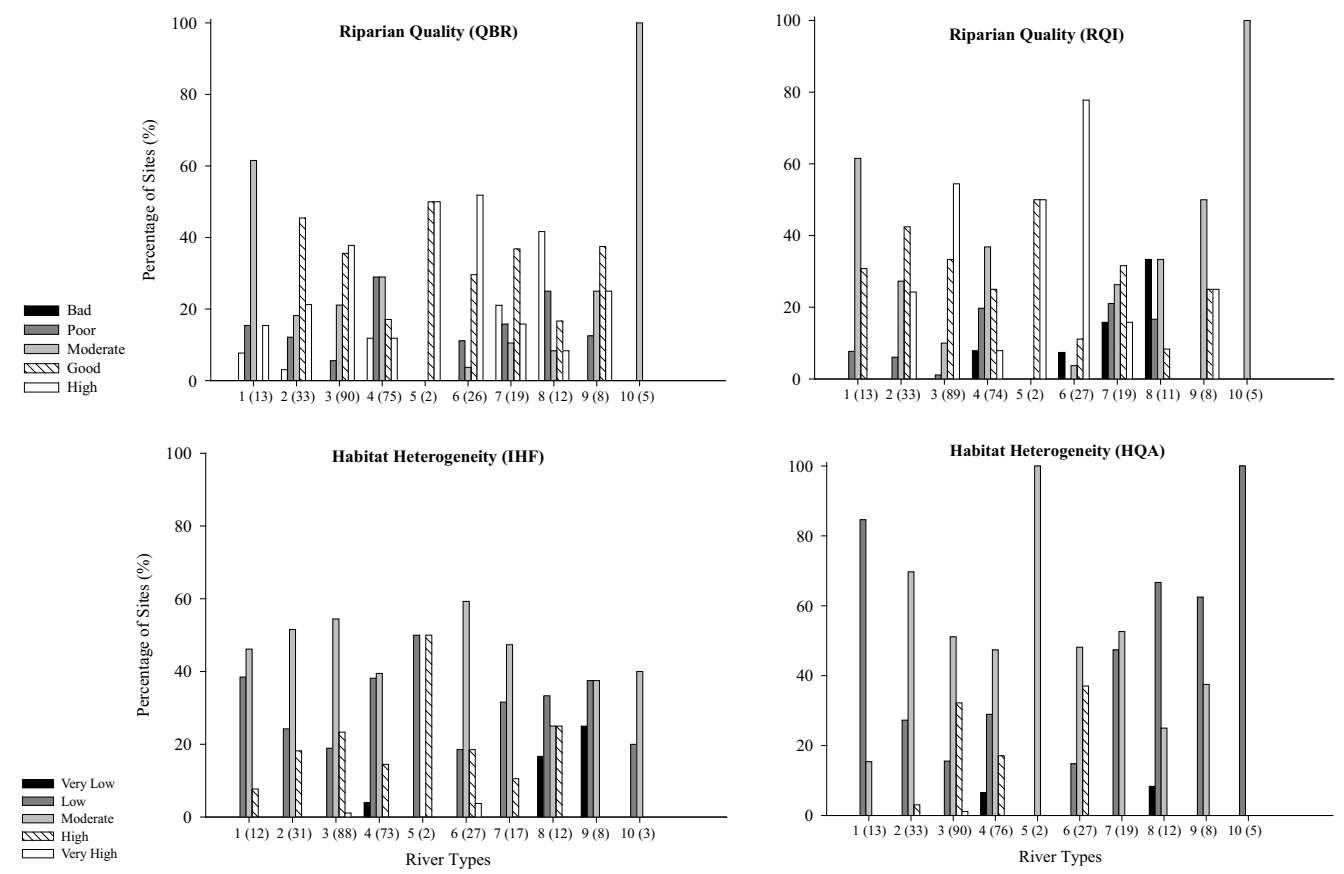

Figure 2. Riparian quality and habitat heterogeneity classification using QBR, RQI, IHF and HQA indices in 10 river types in the Cantabrian region of northern Spain in the summer of 2008. Clasificación de la calidad riparia y la heterogenidad del hábitat utilizando los índices QBR, RQI, IHF y HQA en las 10 tipologías fluviales de la región de Cantabria, norte de España, en el verano de 2008.

reaches of mountainous river types $(3,5,6$ and 9 ; Fig. 2). A total of 96 river reaches throughout the Cantabrian river network met all of the reference condition criteria. The QBR and RQI values were both different between reference and non-reference river reaches and among river types (Table 3).

More than $80 \%$ of the river reaches surveyed contained a moderate to low RHH, while $19 \%$ showed a high habitat diversity using both the IHF and HQA indices. Only one site, in the river type 6 (calcareous wet mountain rivers), reached the maximum IHF value of 100, and none reached the maximum HQA value (Fig. 2). A very low RHH was only found in low-gradient streams in the coastal area (river type 4) or in the southern plateau (river types 8 and 9). The IHF and HQA values were both different among river types. However, there was no difference in $\mathrm{RHH}$ between reference and non-reference river reaches (Table 3 ).

Comparing QBR and RQI values between reference and non-reference conditions, we ob- served that reference sites had a predominantly higher value than the non-reference reaches in all river types, except for RQI in river type 8 (Fig. 3). However, IHF and HQA values did not follow a clear pattern, and in some river types (e.g., type 2, 3 and 4; Fig. 3), the reference condition returned higher values than the non-reference condition, while in other river types the reverse was found (e.g., type 8 and 9; Fig. 3). Moreover, QBR values were the most variable between reference and non-reference conditions in any river type (Fig. 3) in comparison with the RQI.

The variables that entered the regression of RQ and reference conditions were related to the absence of modifications on the river channel and banks (QBR4) and to the composition and structure of the riparian vegetation (RQI3), both increasing the probability of a reach being in reference condition (Table 4). On the other hand, HQA attributes provided a better fit in the RHH regression than the IHF ones. The diversity of aquatic vegetation (IHF7) and of flow types 
Table 3. Results from the two-way analysis of variance for reference condition and river type on QBR, RQI, IHF and HQA values obtained in rivers from Cantabria in the summer of $2008(\mathrm{R}=$ Reference; NR $=$ Non-reference; $\mathrm{df}=\mathrm{degrees}$ of freedom; $\mathrm{F}=\mathrm{F}$ statistic; bold $p$ values are $<0.05)$. Resultados del análisis de la varianza de 2 vías con los factores condición de referencia y tipología de río para los valores de QBR, RQI, IHF y HQA obtenidos en los ríos de Cantabria en el verano del $2008(R=R e f e r e n c i a$; $N R=$ No-referencia $; d=$ grados de libertad $F=$ estadístico $F ;$ el valor de $\mathrm{p}$ en negrita $<0.05$ ).

\begin{tabular}{|c|c|c|c|c|c|c|}
\hline & \multicolumn{3}{|c|}{ QBR } & \multicolumn{3}{|c|}{ RQI } \\
\hline & df & $\mathbf{F}$ & p value & df & $\mathbf{F}$ & p value \\
\hline $\mathrm{R} / \mathrm{NR}$ & 1 & 11.70 & 0.0007 & 1 & 7.36 & 0.0072 \\
\hline River Types & 5 & 4.85 & 0.0003 & 5 & 10.13 & 0.0001 \\
\hline R/NR *River Types & 5 & 0.12 & 0.9884 & 5 & 0.41 & 0.8431 \\
\hline \multirow[t]{2}{*}{ Error } & 235 & & & 238 & & \\
\hline & & IHF & & \multicolumn{3}{|c|}{ HQA } \\
\hline $\mathrm{R} / \mathrm{NR}$ & 1 & 0 & 0.9919 & 1 & 0.47 & 0.4944 \\
\hline River Types & 5 & 4.40 & 0.0008 & 5 & 4.59 & 0.0005 \\
\hline R/NR *River Types & 5 & 0.48 & 0.7913 & 5 & 0.75 & 0.5887 \\
\hline Error & 232 & & & 241 & & \\
\hline
\end{tabular}
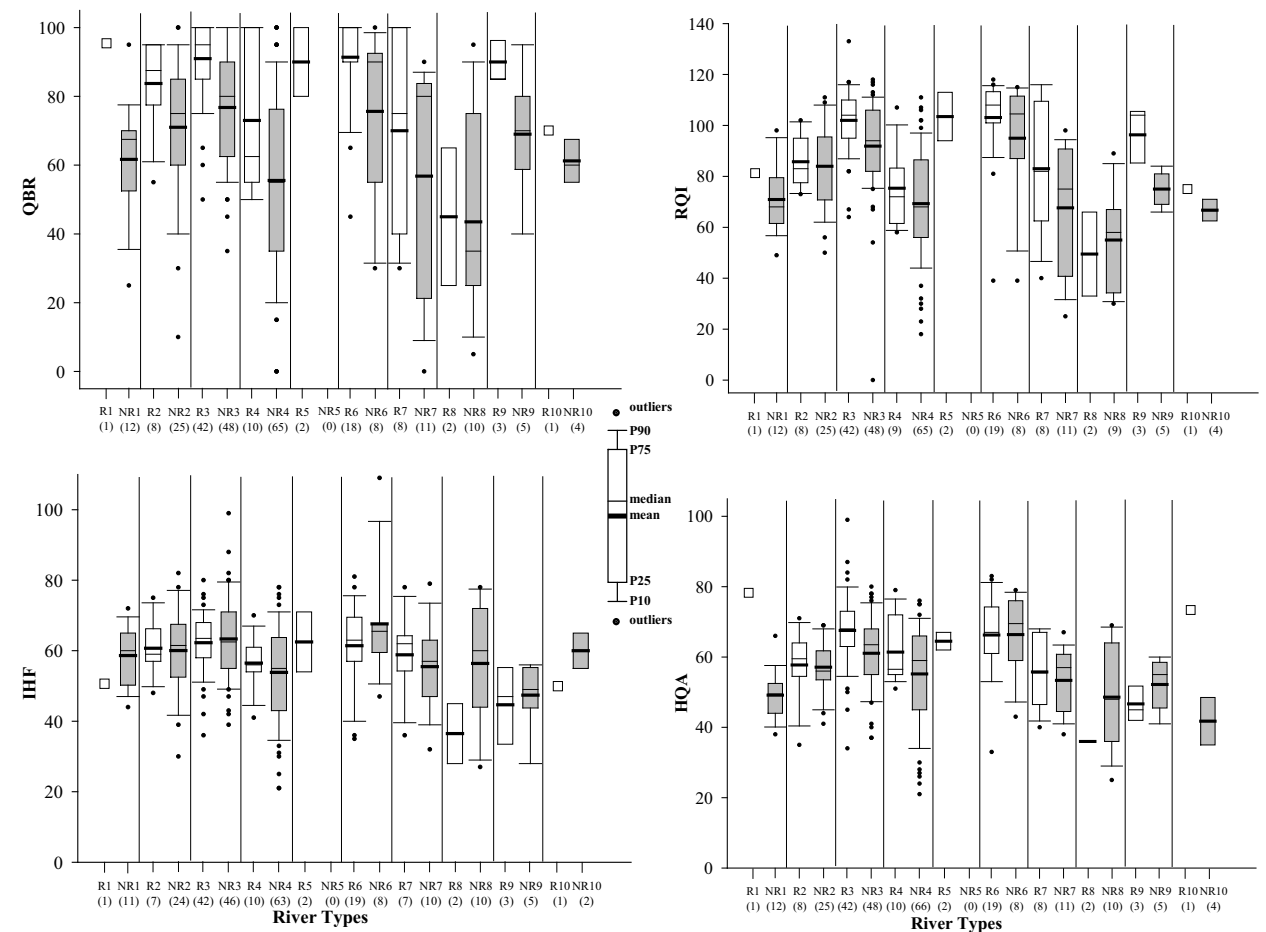

Figure 3. Box plots of QBR, RQI, IHF and HQA values obtained from the rivers of the Cantabrian Region in reference (R: white boxes) and non-reference reaches (NR: grey boxes). The numbers following R and NR are the river type codes described in Table 1, while the numbers within brackets are the number of reaches in each river type. Gráficos de cajas para los valores de $Q B R, R Q I, I H F$ y HQA obtenidos en ríos de la región de Cantabria en tramos de referencia ( $R$ : cajas blancas) y de no-referencia (NR: cajas grises). Los números que siguen a $R$ y NR son los códigos de las tipologías fluviales descritas en la tabla 1 , mientras que los números entre paréntesis indican el número de tramos fluviales en cada tipología. 
Table 4. Results from the binary logistic regression for riparian quality (QBR/RQI) and for habitat heterogeneity (IHF/HQA) assessed in rivers in Cantabria in the summer of 2008 ( $\mathrm{R}=$ Reference; NR = Non-reference; bold $p$ values < 0.05). Resultados de la regresión logística binaria para la calidad del bosque de ribera $(Q B R / R Q I)$ y la heterogeneidad del hábitat (IHF/HQA) evaluado en los ríos de Cantabria, en el verano de $2008(R=$ Referencia; $N R=$ No-referencia; el valor de $\mathrm{p}$ en negrita $<0.05)$.

\begin{tabular}{lcccc}
\hline & Model $\mathbf{R}_{L}^{2}$ & \% $\mathbf{R}$ & \% NR & Total \% \\
\hline QBR/RQI & 0.31 & 56.4 & 79.5 & 71.7 \\
\hline IHF/HQA & 0.26 & 44.7 & 89.9 & 74.4 \\
\hline \multirow{2}{*}{ QBR/RQI } & Variable & $\mathbf{E x p}(\mathbf{B})$ & $\mathbf{p}$ value & \\
\cline { 2 - 5 } & RQI3 & 1.082 & 0.002 & \\
\hline \multirow{2}{*}{ IHF/HQA } & IHF7 & 1.169 & 0.0001 & \\
\cline { 2 - 5 } & HQA1 & 0.941 & 0.011 & \\
\cline { 2 - 5 } & HQA3 & 1.244 & 0.0001 & \\
\cline { 2 - 5 } & HQA7 & 1.245 & 0.0001 & \\
\hline
\end{tabular}
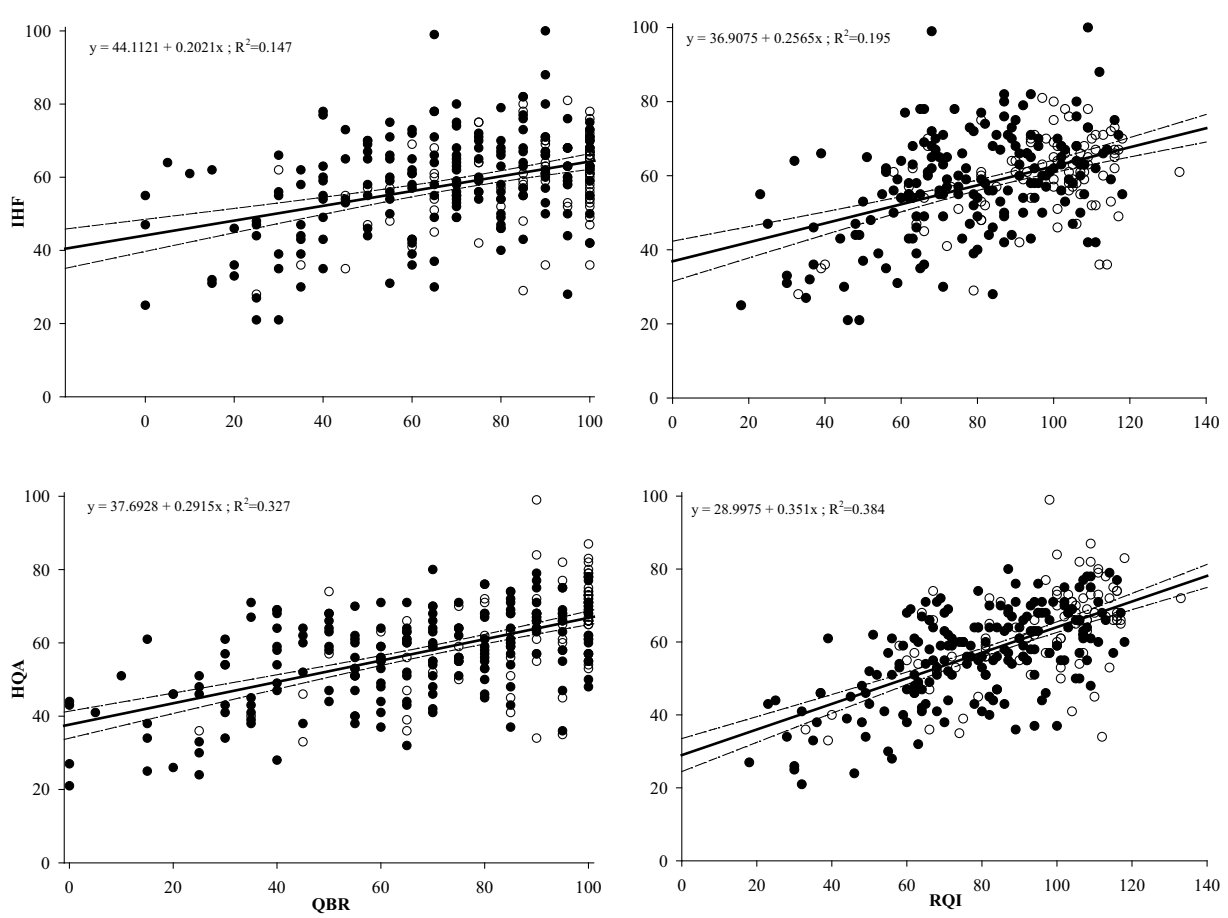

Figure 4. Linear regression results for riparian quality (QBR and RQI) and river habitat heterogeneity (IHF and HQA) assessed in the rivers of the Cantabrian region in the summer of 2008. Reference (o) and non-reference sites $(\bullet)$ are also indicated $(p$ value $<0.05$ for all regressions). Resultados de la regresión lineal entre la calidad riparia (QBR y RQI) y la heterogeneidad del hábitat fluvial (IHF y HQA) evaluados en los ríos de la región de Cantabria en el verano de 2008. Se indican también los sitios de referencia ( o) y los de no-referencia (•; el valor de $\mathrm{p}<0.05$ en todas las regresiones).
(HQA1) increased the probability of a site belonging to a non-reference reach, while the diversity of channel features (HQA3) and of natural land uses (HQA7) increased the probability of the site belonging to a reference condition river reach (Table 4).

RQ and RHH were positively correlated regardless of the index that was used for building the regression, either QBR or RQI against IHF or HQA (Fig. 4). The strongest relationship was obtained between the RQI and HQA indices $\left(r^{2}=0.384 ; p<0.05\right)$. The integrity of the invertebrate communities, measured using the index IASPT, was also positively related to both RQ and RHH (Fig. 5), with a stronger relationship with RQI than with HQA (RQI: $r^{2}=0.37$; HQA: $r^{2}=0.29 ; p<0.05$ for both). 

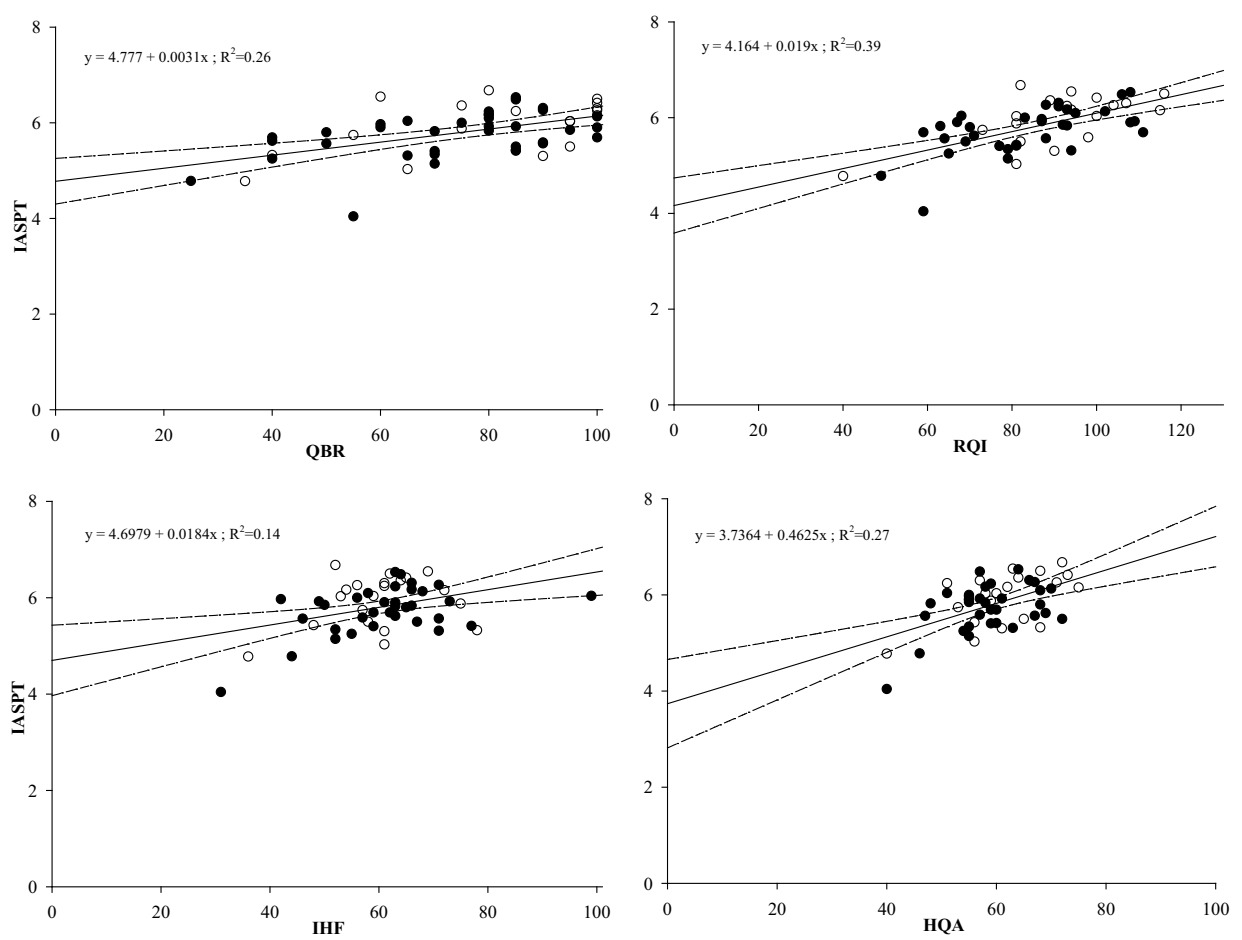

Figure 5. Linear regression results for the invertebrate community index IASPT related to the riparian quality (QBR and RQI) or river habitat heterogeneity (IHF and HQA) assessed in the rivers of the Cantabrian region in the summer of 2008. Reference (o) and non-reference sites $(\bullet)$ are also indicated ( $p$ value $<0.05$ for all regressions). Resultados de la regresión lineal entre el índice de la comunidad de invertebrados IASPT y la calidad riparia (QBR y RQI) y la heterogeneidad del hábitat fluvial (IHF y HQA) evaluados en los ríos de la región de Cantabria en el verano de 2008. Se indican también los sitios de referencia (o) y los de no-referencia (•; el valor de $\mathrm{p}<0.05$ en todas las regresiones).

\section{DISCUSSION}

The QBR and RQI indices performed satisfactorily to distinguish the reference and nonreference sites according to the criteria we established. The values of both indices in the reference sites were always higher than in the non-reference sites irrespective of the river type. However, the binary regressions did not show a relationship between high scores of the indices IHF and HQA and the reference sites. Moreover, reference sites in different river types sometimes had higher or lower RHH values than non-reference sites, suggesting that habitat heterogeneity might not be the best estimator of river habitat quality. As expected, RQ was positively related to RHH and both of those indices were positively correlated with the IASPT macroinvertebrate community metric.

\section{Evaluation of riparian quality}

Riparian quality evaluation is not an easy task because many attributes need to be taken into account when assessing the condition of the riparian vegetation (Collier et al., 1995; Sada et al., 2001; Steiger et al., 2005). The QBR and RQI indices are derived from a relatively easily applied form that is calculated from different riparian attributes for a given river reach (100 to 500 m in length; Munné et al., 2003; González del Tánago et al., 2006). Despite the many attributes measured by each index, only the degree of channel and bank naturalness (absence of modifications, QBR4) and the composition and structure of the riparian vegetation (RQI3) were selected by the reference condition model. The lack of power to predict reach reference conditions from other riparian attributes measured by 
QBR and RQI indices might be caused by a number of factors. First, the application of the QBR and RQI indices may be interpreted differently in the field and their final values are subject to a high degree of subjectivity; for example, in determining the width of the riparian zone that needs to be assessed depending on bank profiles and valley types. Secondly, low scores in some riparian attributes might not be completely related to riparian impairment and could be more related to natural variability of riparian characteristics among river types. This is the case for the bank condition (RQI5) and riparian lateral connectivity with river channel (RQI6) within the RQI index. Moreover, in the QBR index, some of the riparian characteristics score as positive and others as negative within the same attributes, potentially resulting in the same score for one of the four attributes despite completely different situations. For example, a similar score in QBR1 can be obtained depending on combinations of two attributes: (1) the percentage of vegetation cover of the riparian zone (positive) and (2) the degree of lateral connectivity between the riparian vegetation and hillslope vegetation (positive and negative). Finally, the criteria selected for setting the reference conditions in this study may not be completely appropriate because the percentages of pasture or scrub and shrub land uses in the reach catchment were not included as a criteria, and it is well known that human-driven activities within these land uses might deteriorate the RQ (e.g., cattle pasturing; Kauffmann \& Krueger, 1984) and may increase the variability within reference condition sites. However, pasture and shrub and scrub land uses are considered to be less aggressive than the other land uses selected as reference criteria, and having a high percentage of pasture or scrub and shrub land uses in the catchment does not necessarily mean that local riparian condition is impaired. In future studies, this could be addressed by using as a criteria for reference condition the natural land-use coverage within a given buffer zone from the river channel depending on floodplain extent instead of using catchment land uses.

Although QBR and RQI indices resulted in similar values when evaluating $R Q$ in the
Cantabrian rivers, with the largest differences in the high and poor classes, the RQI had slightly stronger relationships with $\mathrm{RHH}$ and with macroinvertebrate communities (IASPT) than the QBR. This could be related to the more continuous nature of the RQI scores, increasing sequentially by 1 up to 140 , than the QBR scores that increase in steps of 5 up to 100 and therefore give its values a more discrete nature (Santner \& Duffy, 1989). Moreover, the positive and negative scores of the four QBR attributes might also contribute to a lower discrimination power and to the larger observed variability even among river reaches in reference conditions (river types 4 and 7 in Fig. 3). Although both of the indices seem to discriminate between high and low RQ in Cantabrian river reaches, the RQI seems to get better results when relating RQ with RHH or macroinvertebrate communities. One of the main drawbacks of using QBR or RQI indices is that $\mathrm{RQ}$ is only evaluated in a 100 to $500 \mathrm{~m}$ river reach, and then this evaluation is extrapolated to larger segments. We believe that evaluation of RQ should be based on a more objective riparian characterisation taking into account river type and floodplain morphology, using satellite, aerial or remote sensing images to quantify the extents and areas along with field work to assess and quantify the structure and composition (Farid et al., 2006; Goetz, 2006; Magdaleno et al., 2010).

\section{Habitat heterogeneity assessment}

The IHF and HQA returned similar results when used to assess habitat heterogeneity in the Cantabrian rivers, with hardly any site reaching a very high RHH (IHF and HQA > 90) and only some types having sites in which habitat heterogeneity was high (IHF $<70$ and HQA $<90$ ) or very low (IHF and HQA < 30). Moreover, RHH was more varied among river types than between reference and non-reference conditions (Table 3). These results indicate that not all river types have the same level of diversity of habitat characteristics and that some river types are naturally more homogeneous, as was the case for low-gradient streams from the coastal area or in the southern plateau in the present study (river types 4 , 
8 and 9 in Fig. 2). Low-gradient streams have also been identified in other studies as having a lower rate of spatial change than higher-gradient streams (Fukushima, 2001). A higher diversity of in-stream characteristics is usually associated with higher gradients, but only up to a threshold, after which certain hydraulic sequences dominate and the diversity of in-stream characteristics does not increase (Grant et al., 1990; Halwas \& Church, 2002). IHF and HQA indices might be appropriate to assess RHH; however, neither of these indices would allow for the determination of the natural rate of change of individual river habitat characteristics because they only provide individual scores for each evaluated attribute. In our opinion, this is a major drawback for completely understanding the dynamics of river habitat characteristics and the effects of different human pressures on them.

In the present study, a higher diversity of aquatic vegetation (IHF7) has been negatively correlated to the reference condition. However, we believe this finding results from a larger cover of different groups of aquatic plants (i.e., filamentous algae, macrophytes, diatoms or mosses) in low-gradient rivers, which are located in coastal areas more prone to human modification, although correlation does not mean causation. Moreover, differences in RHH between RC and NRC sites did not follow the same pattern, with some increasing and others decreasing depending on river type. These differences might be related to the fact that human hydro-morphological impacts have different effects on RHH depending on the type of pressure and on the river type in which they are located. For example, river over-widening, a typical engineering work implemented for flood defence, tends to decrease habitat heterogeneity by creating shallower environments (Kemp et al., 1999). However, its effect will depend on natural water depth profiles and the stream gradient. Moreover, a weir or small dam could increase RHH in a high-gradient stream by creating glide and dammed pool habitats, but it would certainly contribute to a lower RHH in low-gradient streams.

Finally, IHF and HQA values are calculated from the scores of each of the attributes con- sidered. These independent scores might cancel each other out so that a similar final score might come from completely different effects of anthropogenic impacts. This makes it difficult to identify the real effects of different human impacts on the physical attributes of river habitats and riverine biota. Heterogeneity of physical habitat attributes (i.e., diversity of in-stream elements) is important for many aquatic organisms (Power, 1992; Minshall \& Robinson, 1998; Zollhöfer, 1999). However, we believe that RHH is not a good surrogate to evaluate river habitat quality, at least in these Cantabrian rivers, although it might be correlated with habitat quality in many cases and might be useful for identifying hotspots for river conservation (Boon et al., 1998; Walker et al., 2002; Dudgeon et al., 2006; Leathwick et al., 2010). Instead, we share the opinion that physical habitat quality should be evaluated through the degree of deviation of quantified characteristics, such as dominant flow types, dominant substrates, bank profiles or channel measurements calibrated for each river type, as has been proposed in other studies (e.g., Parssons et al., 2004). Using that approach, we might be able to correctly assess whether a given characteristic, such as a high diversity of aquatic vegetation, is common within a fluvial type or if it results from a human pressure.

\section{Relationships between RQ, RHH and macroinvertebrate communities}

As has been shown in other studies using QBR and IHF (Pardo et al., 2002), riparian quality was positively related to river habitat heterogeneity, using any of the indices; however, the relationships were stronger between the RQI and HQA. These results could be due to the more continuous nature of the RQI scores and to the less subjective calculation of the HQA, which is calculated from a RHS database in contrast to the IHF that is calculated directly in the field. Moreover, when looking at the relationships between the different attributes assessed by the RQ and RHH indices, it seems that the extent of the riparian vegetation (QBR1 and RQ2) and the structure of the riparian vegetation (QBR2 and RQI3) were 
the attributes with stronger relationships with the HQA index, as they shared the highest correlations with natural land-use diversity (HQA7) and tree-associated features, such as overhanging boughs and exposed bankside roots (HQA8), and other special features such as debris dam and leafy debris (HQA9; Spearman rank correlation coefficient $>0.5$ for all combinations). On the other hand, only the percentage of shade on the channel (IHF5) from the assessed IHF attributes was significantly correlated with the structure of the riparian vegetation (QBR2; Spearman rank correlation coefficient $=0.5$ ). Thus, it seems that the HQA captures slightly better than the IHF the in-stream channel attributes that are influenced most by the riparian vegetation characteristics in the Cantabrian rivers.

Positive relationships between QBR and IHF indices and macroinvertebrate communities have been shown elsewhere (e.g., Pardo et al., 2002). In the present study, macroinvertebrate community integrity, measured with the IASPT metric, had a stronger positive relationship when using the RQI and HQA than when using QBR and IHF indices. These results could be due to the greater correlations of IASPT with the extent of the riparian vegetation and the structure of the riparian vegetation when using the RQI (Spearman rank correlation coefficient $=0.5,0.6$ and 0.6 for RQ1, RQ2 and RQ3, respectively) than when using the QBR (Spearman rank correlation coefficient = 0.4 for both QBR1 and QBR2). Comparatively, the macroinvertebrate community integrity had a greater correlation with the attributes assessed by the HQA, such as flow type diversity (Spearman rank correlation coefficient $=0.5$ for HQA1), channel feature diversity (Spearman rank correlation coefficient $=0.6$ for HQA3) or natural land uses (Spearman rank correlation coefficient $=0.5$ for HQA7), than with the attributes assessed by the IHF, which was only relevant for the frequency of rapids (Spearman rank correlation coefficient $=0.5$ for IHF2).

The use of the scores of these indices and their attributes to evaluate the strength of the relationships between RQ and RHH and of these two with macroinvertebrate communities might be a good practice in preliminary work. However, a closer study identifying cause and effect relationships will require a more detailed objective quantification and the use of continuous variables to eliminate subjectivity and determine more clear-cut patterns.

\section{CONCLUSIONS}

The RQI index performed slightly better than the QBR for discriminating reference and nonreference conditions in the Cantabrian rivers when considering RQ, while the HQA performed slightly better than the IHF when considering RHH. River habitat heterogeneity is not a good surrogate of river habitat quality in the Cantabrian rivers, although the correlation between them might often be high. Both riparian and river habitat quality assessment should be based on measured, ideally quantitative, key characteristics of riparian and riverine habitats more than on subjective indices, so that midto long-term monitoring programs could gather more precise information regarding the effects of human activities on morphological and structural characteristics of riverine habitats. Moreover, techniques that improve the assessment of riparian and riverine habitat characteristics over a whole river network instead of in patchy river reaches should also be developed so that a more precise catchment perspective is achieved.

\section{ACKNOWLEDGEMENTS}

We thank the multiple people who have helped at different stages in this study from the compilation of the information to the finalisation of the manuscript. This study was partly funded by the Spanish Ministry of Science and Innovation as part of the project MARCE (Ref: CTM-200907447). We would also like to thank two anonymous reviewers whose comments helped to improve the earlier drafts of this paper.

\section{REFERENCES}

ACOSTA, R., B. RÍOS, M. RIERADEVALL \& N. PRAT. 2009. Propuesta de un protocolo de eva- 
luación de la calidad ecológica de ríos andinos (CERA) y su aplicación a dos cuencas en Ecuador y Perú. Limnetica, 28(1): 35-64.

ÁLVAREZ-CABRIA, M., J. BARQUÍN \& J. A. JUANES. 2010. Spatial and seasonal variability of macroinvertebrate metrics: Do macroinvertebrate communities track river health? Ecological Indicators, 10: 370-379.

ÁLVAREZ-CABRIA, M., J. BARQUÍN \& J. A. JUANES. 2011. Macroinvertebrate community dynamics in a temperate European Atlantic river. Do they conform to general ecological theory? Hydrobiologia, 658: 277-291.

ALLAN, J. D. 1996. Stream ecology; Structure and Function of Running Waters. Chapman \& Hall. 388 pp.

AQUEM. 2002. Manual for the application of the AQEM system. A comprehensive method to asses European streams using benthic macroinvertebrates, developed for the purpose of the Water Framework Directive. Version 1.0, February 2002. $202 \mathrm{pp}$.

BARQUÍN, J., B. ONDIVIELA, M. RECIO, M. ÁLVAREZ-CABRIA, F. J. PEÑAS, D. FERNÁNDEZ, A. GÓMEZ, C. ÁLVAREZ \& J. A. JUANES. 2012. Assessing the conservation status of alder-ash alluvial forest and Atlantic salmon in the Natura 2000 river network of Cantabria, Northern Spain. In: River conservation and management. $\mathrm{P}$. J. Boon \& P. J. Raven, (eds.): 191-208. WileyBlackwell. Chichester. UK.

BOON, P. J., J. WILKINSON \& J. MARTIN. 1998. The application of SERCON (System for Evaluating Rivers for Conservation) to a selection of rivers in Britain. Aquatic Conservation: Marine and Freshwater Ecosystems, 8: 597-616.

BROOKS, A. P., G. J. BRIERLEY \& R. G. MILLAR. 2003. The long-term control of vegetation and woody debris on channel and flood-plain evolution: insights from a paired catchment study in southeastern Australia. Geomorphology, 51: 7-29.

COLLIER, K. J., A. B. COOPER, R. J. DAVIESCOLLEY, J. C. RUTHERFORD, B. J. SMITH \& R. B. WILLIAMSON 1995. Managing riparian zones: A contribution to protecting New Zealand's rivers and streams. Volume 1: concepts. Department of Conservation. Wellington, New Zealand. $39 \mathrm{pp}$.

DAVIES-COLLEY, R. J. \& J. C. RUTHERFORD. 2005. Some approaches for measuring and mod- elling riparian shade. Ecological Engineering, 24: 525-530.

DUDGEON, D., A. H. ARTHINGTON, M. O. GESSNER, Z. I. KAWABATA, D. J. KNOWLER, C. LÉVEQUE, R. J. NAIMAN, A. H. PRIEUR-RICHARD, D. SOTO, M. L. J. STIASSNY \& C. A. SULLIVAN. 2006. Freshwater biodiversity: importance, threats, status and conservation challenges. Biological Reviews, 81: 163-182.

EC. 1992. Directive EC/1992/43 of the European parliament and of the Council of 21 May 1992 on the conservation of natural habitats and of wild fauna and flora, Official Journal of the European Communities L 206/7, Brussels: European Commission.

EC. 2000. Directive 2000/60/EC of the European Parliament and of the Council of 23rd October 2000 establishing a framework for Community action in the field of water policy, Official Journal of the European Communities L 327/1, Brussels: European Commission.

ELOSEGI, A. J. R. DÍEZ \& M. MUTZ. 2010. Effects of hydromorphological integrity on biodiversity and functioning of river ecosystems. Hydrobiologia, 657: 199-215.

ELOSEGI, A., L. FLORES \& J. DÍEZ. 2011. The importance of local processes on river habitat characteristics; A Basque stream case study. Limnetica, 30(2): 183-196.

ENVIRONMENT AGENCY. 2003. River Habitat Survey in Britain and Ireland. Field survey guidance manual. Bristol, UK. 68 pp.

FARID, A., D. RAUTENKRANZ, D. C. GOODRICH, S. E. MARSH \& S. SOROOSHIAN. 2006. Riparian vegetation classification from airborne laser scanning data with an emphasis on cottonwood trees. Canadian Journal of Remote Sensing, 32(1): $15-18$.

FERNÁNDEZ, D., J. BARQUÍN \& P. J. RAVEN. 2011. A review of river habitat characterisation methods: indices vs. characterisation protocols. Limnetica, 30(2): 217-234.

FERREIRA, J., J. PÁDUA, S. J. HUGHES, R. M. V. CORTES, S. VARANDAS, N. HOLMES \& P. J. RAVEN. 2011. Adapting and adopting river habitat survey: Problems and solutions for fluvial hydromorphological assessment in Portugal. Limnetica, 30(2): 263-272.

FUKUSHIMA, M. 2001. Salmonid habitat-geomorphology relationships in low gradient streams. Ecology, 82(5): 1238-1246. 
GARÓFANO-GÓMEZ, V., F. MARTÍNEZ-CAPEL, M. PEREDO-PARADA, E. J. O. MARÍN, R. MUÑOZ, R. M. SOARES \& J. L. PINAR-ARENAS. 2011. Assessing hydromorphological and floristic patterns along a regulated mediterranean river; the River Serpis (Spain). Limnetica, 30(2): 307-328.

GESHA. 2008. Redacción del plan marco de gestión de los LICs fluviales de la Comunidad Autónoma de Cantabria. Gobierno de Cantabria. Consejería de Desarrollo Rural, Ganadería, Pesca y Biodiversidad. Santander. 110 pp.

GOETZ, S. J. 2006. Remote sensing of riparian buffers: past, progress and future prospects. Journal of the American Water Resources Association, 42(1): 133-143.

GONZÁLEZ DEL TÁNAGO, M. \& D. GARCÍA DE JALÓN. 2011. Riparian quality index (RQI): A methodology for characterizin and assessing environmental conditions of riparian zones. Limnetica, 30(2): 235-254.

GONZÁLEZ DEL TÁNAGO, M., D. GARCÍA DE JALÓN, F. LARA \& R. GARILLETI. 2006. Índice RQI para la evaluación de las riberas fluviales en el contexto de la directiva marco del agua. Ingeniería Civil, 143: 97-108.

GRANT, G. E., F. J. SWANSON \& M. G. WOLMAN. 1990. Pattern and origin of stepped-bed morphology in high-gradient streams, Western Cascades, Oregon. The Geological Society of American Bulletin, 102(3): 340-352.

HALWAS, K. L. \& M. CHURCH. 2002. Channel units in small, high gradient streams on Vancouver Island, British Columbia Geomorphology, 43(3-4): 243-256

HAURY, J. \& L. G. AÏDARA. 1999. Macrophyte cover and standing crop in the River Scorff and its tributaries (Brittany, northwestern France): scale, patterns and process. Hydrobiologia, 415: 109-115.

JÁIMEZ-CUÉLLAR, P., S. VIVAS, N. BONADA, S. ROBLES, M. MELLADO, M. ÁlVAREZ, J. AVILÉS, J. CASAS, M. ORTEGA, I. PARDO, N. PRAT, M. RIERADEVALL, C. E. SÁINZCANTERO, A. SÁNCHEZ-ORTEGA, M. L. SUÁREZ, M. TORO, M. R. VIDAL-ABARCA, C. ZAMORA-MUÑOZ \& J. ALBA-TERCEDOR. 2002. Protocolo GUADALMED (PRECE). Limnetica, 21(3-4): 187-204.

JOINT NATURE CONSERVATION COMMITTEE. 2007. Second Report by the UK under Article 17 on the implementation of the Habitats Directive from January 2001 to December 2006. JNCC.
Available from: www.jncc.gov.uk/article17. Peterborough, UK. 9 pp.

KAUFFMANN, J. B., R. L. BESCHTA, N. OTTING \& D. LYTJEN. 1997. An ecological perspective of riparian and stream restoration in the western United States. Fisheries, 22(5): 12-24.

KAUFFMANN, J. B. \& W. C. KRUEGER. 1984. Livestock impacts on riparian ecosystems and streamside management implications. A review. Journal of Range Management, 37(5): 430-438.

KEMP, J. L., D. M. HARPER \& G. A. CROSA. 1999. Use of functional habitats to link ecology with morphology and hydrology in river rehabilitation. Aquatic Conservation: Marine and Freshwater Ecosystems, 9(1): 159-178.

LARA, F., R. GARILLETI \& J. A. CALLEJA 2004. La vegetación de ribera de la mitad norte española. Ministerio de Fomento. CEDEX. Madrid. 536 pp.

LEATHWICK, J. R., A. MOILANEN, S. FERRIER \& K. JULIAN. 2010. Complementarity-based conservation prioritization using a community classification, and its application to riverine ecosystems Biological Conservation, 143: 984-991.

LESTER, P. J., S. F. MITCHELL \& D. SCOTT. 1994. Effects of riparian willow trees (Salix fragilis) on macroinvertebrate densities in two small Central Otago, New Zealand, streams. New Zealand Journal of Marine \& Freshwater Research, 28: 267-276.

MAGDALENO, F., R. MARTÍNEZ \& V. ROCH. 2010. Índice RFV para la valoración del estado del bosque de ribera. Ingeniería Civil, 157: 85-96.

MARTÍNEZ, C. \& J. A. FERNANDEZ. 2006. Índices de Alteración Hidrológica en ecosistemas fluviales. Monografías del CEDEX. Ministerio de Fomento, Ministerio de Medio Ambiente. Madrid, Spain. 120 pp.

MINSHALL, G. W. \& C. T. ROBINSON. 1998. Macroinvertebrate community structure in relation to measures of lotic habitat heterogeneity. Archiv für Hydrobiologie, 141(2): 129-151.

MUNNÉ, A., N. PRAT, C. SOLÁ, N. BONADA \& M. RIERADEVALL. 2003. A simple field method for assessing the ecological quality of riparian habitat in rivers and streams: QBR index. Aquatic Conservation: Marine and Freshwater Ecosystems, 13: 147-163.

MUNNÉ, A., C. SOLÁ \& J. PAGÉS. 2006. HIDRI: Protocolo para la valoración de la calidad hidromorfológica de los ríos. Agència Catalana de l'Aigua. Barcelona, Spain. 160 pp. 
MUOTKA, T. \& P. LAASONEN. 2002. Ecosystem recovery in restored headwater streams: the role of enhanced leaf retention. Journal of Applied Ecology, 39(1): 145-156.

NAIMAN, R. J., H. DÉCAMPS \& M. E. MCCLAIN 2005. Riparia. Ecology, conservation, and management of streamside communities. Elsevier. London, UK. 430 pp.

NAVARRO-LLÁCER, C., D. BAEZA \& J. DE LAS HERAS. 2010. Assessment of regulated rivers with indices based on macroinvertebrates, fish and riparian forest in the southeast of Spain. Ecological Indicators, 10: 935-942.

OLLERO, A., D. BALLARÍN, E. DÍAZ, D. MORA, M. SÁNCHEZ, V. ACÍN, M. T. ECHEVARRIA, D. GRANADO, A. IBISATE, L. SÁNCHEZ \& N. SÁNCHEZ. 2008. IHG: Un índice para la valoración hidrogeomorfológica de sistemas fluviales. Limnetica, 27(1): 171-188.

OLLERO, A., A. IBISATE, L. E. GONZALO, V. ACÍN, D. BALLARÍN, E. DÍAZ, S. DOMENECH, M. GIMENO, D. GRANADO, J. H. GARCÍA, D. MORA \& M. SÁNCHEZ. 2011. The IHG index for hydromorphological quality assessment of rivers and streams: Updated version. Limnetica, 30(2): 255-260.

PARDO, I., M. ÁLVAREZ, J. CASAS, J. L. MORENO, S. VIVAS, N. BONADA, J. ALBA-TERCEDOR, P. JÁIMEZ-CUÉLLAR, G. MOYÁ, N. PRAT, S. ROBLES, M. L. SUÁREZ, M. TORO \& M. R. VIDAL-ABARCA. 2002. El hábitat de los ríos mediterráneos. Diseño de un índice de diversidad de hábitat. Limnetica, 21(3-4): 115-133.

PARSSONS, M., M. C. THOMS \& R. H. NORRIS. 2004. Development of a standardised approach to river habitat assessment in Australia. Environmental Monitoring and Assessment, 98: 109-130.

POWER, M. E. 1992. Habitat heterogeneity and the functional significance of fish in river food webs. Ecology, 73(5): 1675-1688.

QUINN, J. M., A. B. COOPER, M. J. STROUD \& G. P. BURRELL. 1997. Shade effects on stream periphyton and invertebrates: an experiment in streamside channels. New Zealand Journal of Marine \& Freshwater Research, 31: 665-683.

R DEVELOPMENT CORE TEAM. 2008. R: A Language and Environment for Statistical Computing. R Foundation for Statistical Computing, Vienna, Austria. ISBN: 3-900051-07-0, http: //www.R-project.org.
RAVEN, P. J., P. FOX, M. EVERARD, N. T. H. HOLMES \& F. H. DAWSON. 1997. River Habitat Survey: a new system for classifying rivers according to their habitat quality. In: Freshwater quality: Defining the indefinable? P. J. Boon \& D. L. Howell, (eds.): 215-234. The Stationery Office, Edinburgh.UK.

RAVEN, P. J., N. HOLMES, P. SCARLETT, M. T. FURSE \& J. BARQUÍN. 2009. River Habitat Survey in the Picos de Europa, Northern Spain: Results from 2008. Environment Agency \& Centre for Ecology and Hydrology. Bristol, UK. 42 pp.

RAVEN, P. J., N. T. H. HOLMES, F. H. DAWSON \& M. EVERARD. 1998. Quality assessment using River Habitat Survey data. Aquatic Conservation: Marine and Freshwater Ecosystems, 8: 477-499.

RAVEN, P. J., N. T. H. HOLMES, I. P. VAUGHAN, F. H. DAWSON \& P. SCARLETT. 2010. Benchmarking habitat quality: observations using River Habitat Survey on near-natural streams and rivers in northern and western Europe. Aquatic Conservation: Marine and Freshwater Ecosystems, 20: S13-S30.

SADA, D. W., J. E. WILLIAMS, J. C. SILVEY, A. HALFORD, J. RAMAKKA, P. SUMMERS \& L. LEWIS. 2001. Riparian area management: A guide to managing, restoring, and conserving springs in the Western United States. Technical Reference 1737-17. Bureau of Land and Management. Denver, Colorado. $70 \mathrm{pp}$.

SANTNER, T. J. \& D. E. DUFFY 1989. The statistical analysis of discrete data. Springer Verlag. New York, U.S.A. 388 pp.

SOLÀ, C., M. ORDEIX, Q. POU-ROVIRA, N. SELLARÈS, A. QUERALT, M. BARDINA, A. CASAMITJANA \& A. MUNNÉ. 2011. The longitudinal connectivity within the hydromorphological quality assessment of rivers. The ICF index and its application to Catalan rivers. Limnetica, 30(2): 273-292.

STEIGER, J., E. TABACCHI, S. DUFOUR, D. CORENBLIT \& J.-L. PEIRY. 2005. Hydrogeomorphic processes affecting riparian habitat within alluvial channel-floodplain river systems: a review for the temperate zone. River Research and Applications, 21: 719-737.

STODDARD, J. L., D. P. LARSEN, C. P. HAWKINS, R. K. JOHNSON \& R. H. NORRIS. 2006. Setting expectations for the ecological condition of streams: the concept of reference condition. Ecological Applications, 16(4): 1267-1276.

TACHET, H., P. RICHOUX, M. BOURNAUD \& P. USSEGLIO-POLATERA 2002. Invertebres d'eau 
Douce. Systematique, biologie, ecologie. CNRS Editions. Paris. 587 pp.

VIEIRA-LANERA, R. 2000. Las larvas de los tricópteros de Galicia (Insecta: Trichoptera). Ph.D. Thesis. Universidad de Santiago de Compostela, Santiago de Compostela, España. 611 pp.

WALKER, J., M. DIAMOND \& M. NAURA. 2002. The development of physical quality objectives for rivers in England and Wales. Aquatic Conservation: Marine and Freshwater Ecosystems, 12: 381390.

ZOLLHÖFER, J. M. 1999. Spring biotopes in northern Switzerland: Habitat heterogeneity, zoobenthic communities and colonization dynamics. Ph.D. Thesis. Swiss Federal Institute of Science and Technology, Zürich, Switzerland. 138 pp. 